\title{
Behçet Hastalarında Paterji Testi
}

\section{Pathergy Test in Behçet's Disease}

\author{
Yunus DURMAZ ${ }^{1}$
}

${ }^{1}$ Karabük Eğitim ve Araştırma Hastanesi, Fiziksel Tıp ve Rehabilitasyon Anabilim Dalı, Romatoloji Kliniği, Karabük, TÜRKiYE

öz.

Amaç: Çalışmanın birincil amacı aktif Behçet Hastalarında (BH), ilk tanı anındaki paterji pozitiflik sıklığını araştırmaktır. İkincil amacı ise paterji durumu ile sosyodemografik, klinik ve laboratuvar özellikleri karşılaştırmaktır.

Materyal ve Metod: Çalışmada $110 \mathrm{BH}$ retrospektif olarak incelendi. Hastaların ilk tanı anındaki sosyodemografik özellikleri (yaş, cinsiyet), klinik bulguları, paterji test (PT) sonuçları, sedimentasyon ( $\mathrm{mm} / \mathrm{sa}$ ) ve C-reaktif protein (CRP) $(\mathrm{mg} / \mathrm{L})$ değerleri kayıt edildi. Hastalık semptomlarının başlangıç yaşı < 40 olanlar klasik başlangıçlı, $\geq 40$ olanlar geç başlangıçı BH olarak kabul edildi. Hastalık aktivitesi için Krause Behçet Hastalığı Klinik Aktivite Skoru kullanıldı.

Bulgular: Yüz on Behçet hastasının 36'sında (\%32.7) PT'nin pozitif olduğu görüldü. PT pozitif hastaların 31'inde (\%86.1) genital ülser, 9'unda (\%25.0) artrit, 7'sinde (\%19.4) üveit, 10'unda (\%27.8) derin ven trombozu, 10'unda (\%27.8) papulopüstüler lezyon, 6'sında (\%16.7) eritema nodozum, $1^{\prime}$ inde (\%2.8) nöroparankimal 1'inde de (\%2.8) nörovasküler tutulum mevcuttu. PT negatif olan hastalarda bu sıklıklar sırası ile 66 (\%89.2), 19 (\%25.7), 22 (\%29.7), 19 (\%25.7), 12 (\%16.2), 7 (\%9.5), 2 (\%2.7), 1 (\%1.4) idi. PT’nin pozitiflik durumu ile klinik bulguların görülme sıkıkları istatistiksel açıdan farklı değildi ( $>>0.05)$. PT pozitif hastalarda sedimentasyon $(\mathrm{mm} / \mathrm{sa})$ ortanca değeri $16(2-98)$ iken CRP (mg/L) ortanca değeri 3.78 (0-126) idi. PT negatif olanlarda bu değerler sırası ile 17.5 (1-108) ve 4.5 (0-121) idi. PT'nin pozitiflik durumu ile sedimentasyon $(\mathrm{mm} / \mathrm{sa})$ ve CRP $(\mathrm{mg} / \mathrm{L})$ ortanca değerleri karşılaştıııldığında istatistiksel anlamlı farklılık görülemedi ( $p>0.05)$. PT pozitif hastalarda, hastalık aktivitesi toplam skoru ortanca değeri 3 (1-6) iken PT negatif olanlarda bu ortanca değer 3 (1-7) idi. PT pozitif ve negatif olan hastalar hastalık aktivitesi toplam skorları açııından karşılaştırıldığında istatistiksel anlamlı farklıık yoktu $(p=0.494)$. Klasik yaş başlangıçlı hastalar içerisinde PT'si pozitif olan 34 (\%33.3) hasta var iken geç yaş başlangıçı olanlar içerisinde PT'si pozitif olan 2 (\%25.0) hasta vardı. Klasik ve geç başlangıçlı hastalar, PT pozitiflik sıkııları açısından karşılaştırıldığında istatistiksel anlamlı farklıık bulunamadı $(p=1.000)$.

Sonuç: PT pozitifliğinin hastalığın klinik şiddetini tahmin etmede ve BH için tedaviyi düzenlemede yararı halen tartışmalıdır ve daha fazla araştırma gerekmektedir. Belki de PT'nin duyarılığını artıracak yeni, standardize test yöntemleri bu belirsizliği çözecek ve klinisyenler için testi daha değerli hale getirecektir.

Anahtar kelimeler: Behçet hastalığı, Hastalık Aktivitesi, Paterji Testi

Abstract

Background: The primary aim of the study is to investigate the frequency of pathergy positivity in active BD patients at the time of the first diagnosis. Its secondary aim is to compare the status of pathergy with sociodemographic, clinical and laboratory characteristics.

Materials and Methods: In this study, $110 \mathrm{BHs}$ were analyzed retrospectively. Sociodemographic characteristics (age, gender), clinical findings, PT status, sedimentation $(\mathrm{mm} / \mathrm{hr}$ ) and C-reactive protein (CRP) $(\mathrm{mg} / \mathrm{L})$ values of the patients at the time of initial diagnosis were recorded. Age of onset of disease symptoms $<40$ were accepted as classical onset, patients $\geq 40$ as late-onset BD. Krause Behçet's Disease Clinical Activity Score was used for disease activity.

Results: S PT was found to be positive in 36 (32.7\%) of 110 patients with Behçet's disease. In PT positive patients; there was genital ulcer in $31(86.1 \%)$, arthritis in $9(25.0 \%)$, uveitis in $7(19.4 \%)$, deep vein thrombosis in $10(27.8 \%)$, papulopustular lesion in $10(27.8 \%)$, erythema nodosum in $6(16.7 \%)$, neuropenchymal involvement in $1(2.8 \%)$ and neurovascular involvement in $1(2.8 \%)$. In PT negative patients, these frequencies were $66(89.2 \%), 19(25.7 \%), 22$ $(29.7 \%), 19(25.7 \%), 12(16.2 \%), 7(9.5 \%), 2(2.7 \%)$ and $1(1.4 \%)$, respectively. The positivity of PT and the frequency of clinical findings were not statistically different $(\mathrm{p}>0.05)$. Median value of sedimentation $(\mathrm{mm} / \mathrm{h})$ was $16(2-98)$, while the median value of CRP (mg/L) was 3.78 (0-126) in PT positive Behçet patients. In PT negative patients, these values were 17.5 (1-108) and 4.5 (0-121), respectively. When the positivity of PT and the median values of sedimentation $(\mathrm{mm} / \mathrm{hr})$ and CRP $(\mathrm{mg} / \mathrm{L})$ were compared, no significant difference was found $(\mathrm{p}>0.05)$. Median value of disease activity total score was 3 (1-6) in PT positive patients, while this median value was 3 (1-7) in PT negative patients. When PT positive and negative patients were compared in terms of disease activity total scores, there was no significant difference $(\mathrm{p}=0.494)$. While there were $34(33.3 \%)$ patients with positive PT among classical age-onset patients, there were $2(25.0 \%)$ among those with late onset. When classical and late-onset patients were compared in terms of PT positivity, no significant difference was found ( $p=1.000)$.

Conclusions: The benefit of PT positivity in predicting the clinical severity of the disease and regulating treatment for $B D$ is still controversial and requires further research. Perhaps new, standardized test methods that will increase the sensitivity of PT will resolve this uncertainty and make the test more valuable for clinicians.

Key Words: Behçet's disease, Disease Activity, Pathergy Test
Corresponding Author/Sorumlu Yazar

Dr. Yunus DURMAZ

Karabük Eğitim ve Araştırma Hastanesi, Fiziksel Tip ve

Rehabilitasyon AD, Romatoloji Kliniği, 78200, Karabük, TÜRKIYE

E-mail: durmaz_y@hotmail.com

Received / Geliș Tarihi: 22.02.2021

Accepted / Kabul Tarihi: 12.03.2021

DOI: $10.35440 /$ hutfd. 884782 


\section{Giriş}

Behçet hastalığı (BH) mukokutanöz tutulum başta olmak üzere çoklu organ tutulumu yapabilen kronik inflamatuvar bir vaskülittir. Çeşitli genetik, çevresel ve immünolojik faktörlerin patogenezinde rol aldığı bilinmesine rağmen halen hastalığın etiyopatogenezi tam olarak anlaşılamamıştır (1-3). Sınıflama kriterlerinden en fazla tercih edileni, 1990 yılında tanımlanmış olan, Uluslararası Behçet Hastalığı Çalışma Grubu sınıflama kriterleridir (4). Bu kriterlerin içerisinde paterji test (PT) pozitifliği de bulunmaktadır.

Paterji reaksiyonu, ilk kez 1937 yılında Blobner tarafından minör travmaya yanıt olarak değişen doku reaktivitesi durumu olarak tanımlanmıştır (5). Paterji lezyonları sıklıkla cilt travması sonrası papül olarak kalabilen veya steril püstüllere ilerleyebilen, eritemli sertleşme ile kendini göstermektedir. PT pozitifliğinin kesin oluşum mekanizması henüz tam olarak bilinmemektedir. Histopatolojik çalışmalar sonucunda hem dermiste hem de epidermisten sık görülen patolojik bulgu; mikst tip inflamatuar hücre infiltratlarıdır (6). Birçok hastalıkta PT pozitifliği bildirilse de PT sadece $\mathrm{BH}$ sınıflama kriterleri içerisinde kendine yer bulmuştur (4). Bununla birlikte, paterji reaksiyonu sadece deri ile sınırlı değildir ve daha genel olarak, yaralanma sonrası herhangi bir organda hiperreaktivite durumu olarak tanımlanabilir (7). BH'lerde deri dışı bölgelerdeki paterji reaksiyonuna örnek olarak, artrosentezden sonra sinovitin gelişmesi, intraoküler enjeksiyonu takiben üveitin gelişmesi ve vasküler anastomoz cerrahisi sonrası anevrizmaların gelişmesi verilebilir (7).

Behçet hastalığının aktif dönemlerinde coğrafik olarak farklılık göstermekle beraber paterji sıklığı \%50-80 arasında bildirilmiştir (8). Klinik gözlemimiz günümüzde ilk tanı anındaki aktif BH'lerde bu sıklığın daha düşük olduğu yönündedir. Bu çalışmanın amacı, BH tanısını kliniğimizde alan hastalarda, ilk tanı anındaki paterji pozitiflik sıklığını araştırmaktır. Ayrıca paterji pozitiflik durumu ile ilk tanı anındaki sosyodemografik, klinik ve laboratuvar özellikleri karşılaştırmaktır.

\section{Materyal ve Metod}

Çalışma başlangıcında, romatoloji kliniğinde 01.09.201601.09.2020 tarihleri arasında, Uluslararası Behçet HastaIığı Çalışma Grubu sınıflama kriterlerine (4) göre BH tanısı almış 18 yaş ve üstü 136 hasta retrospektif olarak incelendi. Dosya bilgileri tam olarak ulaşılabilen $110 \mathrm{BH}$ çalışmaya dahil edildi. Çalışmaya $\mathrm{BH}$ dışındaki diğer inflamatuvar romatolojik hastalığı olanlar ile BH dışında PT pozitifliği yapabilecek hastalığı olanlar (inflamatuvar barsak hastalığı, piyoderma gangrenozum, sweet sendromu gibi nötrofilik dermatozlar vb.), 18 yaşın altında olanlar, gebe olanlar, halihazırda başka bir nedenle immunsüpresan tedavi alanlar dahil edilmedi. Çalışmaya alınan hastaların ilk tanı anındaki yaş (yıl), cinsiyeti gibi sosyodemografik özellikleri ile ilk tanı anındaki hastalığa ait klinik bulguları [ oral aft (OA), genital ülser (GÜ), papülopüstüler lezyonlar
(PPL), eritema nodozum (EN), üveit, derin ven trombozu (DVT), pulmoner arter anevrizması (PAA), Budd Chiari Sendromu (BCS), nörovasküler, nöroparankimal tutulum, gastrointestinal (GiS) tutulum, renal tutulum vb. ] kayıt edildi. Hastaların semptom başlangıç yaşı 40'ın altında olanlar klasik başlangıçlı BH olarak kabul edilirken 40 yaş ve üzeri olanlar ise geç başlangıçlı $\mathrm{BH}$ olarak kabul edildi (9). Yine hastaların ilk tanı anındaki sedimentasyon $(\mathrm{mm} / \mathrm{sa})$ ve C-reaktif protein (CRP) $(\mathrm{mg} / \mathrm{L})$ değerleri not edildi.

Paterji testi uygulaması kliniğimizde rutin olarak avasküler ön kol ekstansör yüzüne herhangi bir cerrahi sterilizasyon veya dezenfeksiyon işlemi yapılmadan, 20 gauge'lık enjektör iğnesi ile sağ ve sol kol olmak üzere en az altı ayrı noktaya pikür yapılarak uygulanmaktadır. Reaksiyonun gelişebilmesi için pikürün dermise kadar inecek derinlikte $(5 \mathrm{~mm})$ ve 45 derecelik açı ile uygulanmasına dikkat edilmektedir. Pikür alanında 24. saatte başlayan ve 48 . saatte maksimum olan, $2 \mathrm{~mm}$ 'den daha büyük eritemli papül veya püstül oluşumu pozitif reaksiyon olarak kabul edilirken sadece iğne izi (eritem) var ise negatif olarak kabul edilmektedir (10). Paterji testi sonrası deri reaksiyonu olarak gelişen püstül, papülden daha şiddetli bir reaksiyondur (10). Hastaya uygulanan altı pikür içerisinden en az biri püstül ise püstül saptananlar olarak, sadece papül gelişenler ise papül saptananlar olarak sınıflandırıldı. Ayrıca PT için yapılan altı pikürden kaç tanesinin pozitif geldiği pozitif saptanan pikür sayısı olarak değerlendirildi. İlk tanı anındaki hastalık aktivitesinin belirlenmesinde Krause Behçet Hastalığı Klinik Aktivite Skoru kullanıldı (11). Bu skorlamaya göre her hafif semptom (OA, GÜ, EN, PPL gibi tipik deri lezyonları ve artralji) için 1 puan, her orta şiddetli semptom (artrit, bacaklarda DVT, anterior üveit, GiS tutulum) için 2 puan ve her şiddetli semptom (posterior üveit / panüveit, retinal vaskülit, arteriyel tromboz, nörobehçet ) için 3 puan verilerek, toplam skor elde edildi. Toplam skora göre hastalar düşük (<4), orta (4-6) ve yüksek ( $\geq 7)$ hastalık aktivitesi olmak üzere üç gruba ayrıldı (11).

Çalışma protokolü Karabük Üniversitesi Tıp Fakültesi yerel etik kurulu tarafından onaylandı (tarih: 16.11.2020, karar sayısı: E-77192459-050.99-47176). Çalışma Helsinki Bildirgesi ilkelerine uygun olarak yapıldı.

Verilerin normal dağılıp dağılmadığına Kolmogorov-smirnov testi ile karar verildi. Normal dağılan veriler için ortalama ve standart sapma, normal dağılmayan veriler için ortanca ve minimum-maksimum değerleri verildi. Normal dağılan verilerin karşılaştırılması için Independent sample t-test, normal dağılmayanlar için Mann Whitney $U$ testi kullanıldı. Gruplar arası farkı belirlemek için Pearson Kikare ve Fisher Exact Test kullanıldı. Normal dağılıma uymayan değişkenlerin arasındaki ilişki Spearman korelasyon testi ile analiz edildi. Korelasyonun katsayısı şu şekilde yorumlandı (12):

- $\quad 0,900$ ila $1.000(-0.900$ ila -1.000$)=$ Çok güçlü düzeyde pozitif (negatif) korelasyon 
- $\quad 0.700$ ila $.900(-0.700$ ila -0.900$)=$ Güçlü düzeyde pozitif (negatif) korelasyon

- $\quad 0.500$ ila $0.700(-0.500$ ila -0.700$)=$ Orta düzeyde pozitif (negatif) korelasyon

- $\quad 0.300$ ila $0.500(-0.300$ ila -0.500$)=$ Düşük düzeyde pozitif (negatif) korelasyon

- $\quad 0.000$ ila $0.300(0.000$ ila -0.300$)=$ inmal edilebilir korelasyon

Anlamlılık için $\mathrm{p}<0.05$ değeri kabul edildi. İstatiksel analiz için SPSS 26 versiyonu kullanıldı (SPSS Inc., IBM Co., and Chicago, IL, USA).

\section{Bulgular}

Çalışmaya 64 (\% 58.2) erkek ve 46 (\% 41.8) kadın hasta dahil oldu. Hastaların yaş ortalaması $31.16 \pm 6.97$ (yıl) iken CRP ortanca değeri 4.25 (0-126) (mg/L), sedimentasyon ortanca değeri 16.5 (1-108) (mm/sa) idi. Araştırmaya dahil olan hastaların 102'si (\%92.7) klasik yaş başlangıçlı iken 8'i (\%7.3) geç yaş başlangıçlı hastalardan oluşuyordu.

Tablo 1. Behçet Hastalarına Ait Sosyodemografik, Laboratuvar ve Klinik Bulguların Paterji Test Durumlarına Göre İstatistiksel Açıdan Karşılaştırılması

\begin{tabular}{|c|c|c|c|c|}
\hline \multirow{2}{*}{\multicolumn{2}{|c|}{ Hastalık Başlangıç Yaşı (yıl) ortalama $\pm S S$}} & PTP $\mathrm{n}=36$ & PTN $n=74$ & p değeri \\
\hline & & $31.63 \pm 6.40$ & $30.93 \pm 7.26$ & $0.620^{\mathrm{a}}$ \\
\hline \multirow[t]{2}{*}{ Cinsiyet $n(\%)$} & Erkek & $23(63.9)$ & $41(55.4)$ & \multirow[t]{2}{*}{$0.397^{b}$} \\
\hline & Kadın & $13(36.1)$ & $33(44.6)$ & \\
\hline \multicolumn{2}{|c|}{$\begin{array}{l}\text { Sedimentasyon (mm/sa) ortanca (min- } \\
\text { max) }\end{array}$} & $16(2-98)$ & $17.5(1-108)$ & $0.873^{c}$ \\
\hline \multicolumn{2}{|c|}{ CRP (mg/L) ortanca (min-max) } & $3.78(0-126)$ & $4.5(0-121)$ & $0.530^{c}$ \\
\hline \multicolumn{2}{|c|}{$\begin{array}{l}\text { Krause Behçet Hastalı̆ı̆ Klinik Aktivite } \\
\text { Toplam Skoru ortanca (min-max) }\end{array}$} & $3(1-6)$ & $3(1-7)$ & $0.494^{c}$ \\
\hline \multirow{3}{*}{$\begin{array}{l}\text { Krause Behçet Hastalı̆̆ı Kli- } \\
\text { nik Aktivite Skoruna Göre } \\
\text { Hastalık Evrelemesi n(\%) }\end{array}$} & Düşük & $31(86.1)$ & $65(87.8)$ & \multirow[t]{3}{*}{$0.709^{b}$} \\
\hline & Orta & $5(13.9)$ & $8(10.8)$ & \\
\hline & Yüksek & $0(0)$ & $1(1.4)$ & \\
\hline \multirow[t]{2}{*}{ Genital Ülser $n(\%)$} & $E$ & $31(86.1)$ & $66(89.2)$ & \multirow[t]{2}{*}{$0.754^{\mathrm{d}}$} \\
\hline & H & $5(13.9)$ & $8(10.8)$ & \\
\hline \multirow[t]{2}{*}{ Artrit $n(\%)$} & E & $9(25.0)$ & $19(25.7)$ & \multirow[t]{2}{*}{$0.939^{b}$} \\
\hline & $\mathrm{H}$ & $27(75.0)$ & $55(74.3)$ & \\
\hline \multirow[t]{2}{*}{ Üveit n(\%) } & $E$ & $7(19.4)$ & $22(29.7)$ & \multirow[t]{2}{*}{$0.251^{b}$} \\
\hline & $\mathrm{H}$ & $29(80.6)$ & $52(70.3)$ & \\
\hline \multirow[t]{2}{*}{ Derin Ven Trombozu n(\%) } & E & $10(27.8)$ & $19(25.7)$ & \multirow[t]{2}{*}{$0.814^{b}$} \\
\hline & $\mathbf{H}$ & $26(72.2)$ & $55(74.3)$ & \\
\hline \multirow{2}{*}{$\begin{array}{l}\text { Papülopüstüler Lezyon } \\
\mathrm{n}(\%)\end{array}$} & E & $10(27.8)$ & $12(16.2)$ & \multirow[t]{2}{*}{$0.155^{\mathrm{b}}$} \\
\hline & H & $26(72.2)$ & $62(83.8)$ & \\
\hline \multirow[t]{2}{*}{ Eritema Nodozum n(\%) } & E & $6(16.7)$ & $7(9.5)$ & \multirow[t]{2}{*}{$0.347^{d}$} \\
\hline & $\mathrm{H}$ & $30(83.3)$ & $67(90.5)$ & \\
\hline \multirow{2}{*}{$\begin{array}{l}\begin{array}{l}\text { Nöroparankimal Tutulum } \\
\mathrm{n}(\%)\end{array} \\
\end{array}$} & $\mathbf{E}$ & $1(2.8)$ & $2(2.7)$ & \multirow[t]{2}{*}{$1.000^{d}$} \\
\hline & H & $35(97.2)$ & $72(97.3)$ & \\
\hline \multirow{2}{*}{$\begin{array}{l}\text { Nörovasküler } \quad \text { Tutulum } \\
\mathrm{n}(\%)\end{array}$} & $\mathrm{E}$ & $1(2.8)$ & $1(1.4)$ & \multirow[t]{2}{*}{$0.549^{d}$} \\
\hline & $\mathrm{H}$ & $35(97.2)$ & $73(98.6)$ & \\
\hline
\end{tabular}

Anlamlılık düzeyi $p<0.05$, a: Independent sample t-test. $b$ : Pearson $\chi^{2}$ test, c: Mann Whitney U testi, d: Fisher Exact test, PTP: Paterji Test Pozitifliği, PTN: Paterji Test Negatifliği, CRP: C-Reaktif Protein, E: Evet, H: Hayır, SS: Standart sapma, min: minimum, max: maksimum, mm: milimetre, sa: saat, mg: miligram, L: Litre

Çalışmaya dahil edilen hastaların 36'sında (\%32.7) PT pozitifliği saptandı. PT pozitif saptanan hastaların 29'unda (\%15.5) paterji testine deri reaksiyonu olarak papül saptanırken 7'sinde (\%6.4) püstül saptandı. Hastalara uygulanan 6 pikür içerisinde pozitif saptanan pikür sayısı ortanca değeri 0 (0-3) bulundu.

Çalışmaya dahil edilen hastaların 110'unda (\%100) OA, 97 'sinde (\% 88.2) GÜ, $28^{\prime}$ inde (\% 25.5) artrit, 29'unda (\% 26.4) üveit, 29‘unda (\% 26.4) DVT, 22‘sinde (\% 20) PPL, 13‘ünde (\% 11.8) EN, 3’ünde (\% 2.7) nöroparankimal tutulum, 2'sinde (\% 1.8) nörovasküler tutulum ile başlangıç mevcuttu. Hiçbir hastada PAA, BCS ve Gis tutulumu ile başlangıç mevcut değildi.

Tablo 2. Behçet Hastalığına Ait Yaş, Klinik ve Laboratuvar Bulgularının Cinsiyet Açısından İstatistiksel Karşılaş̧ııılması

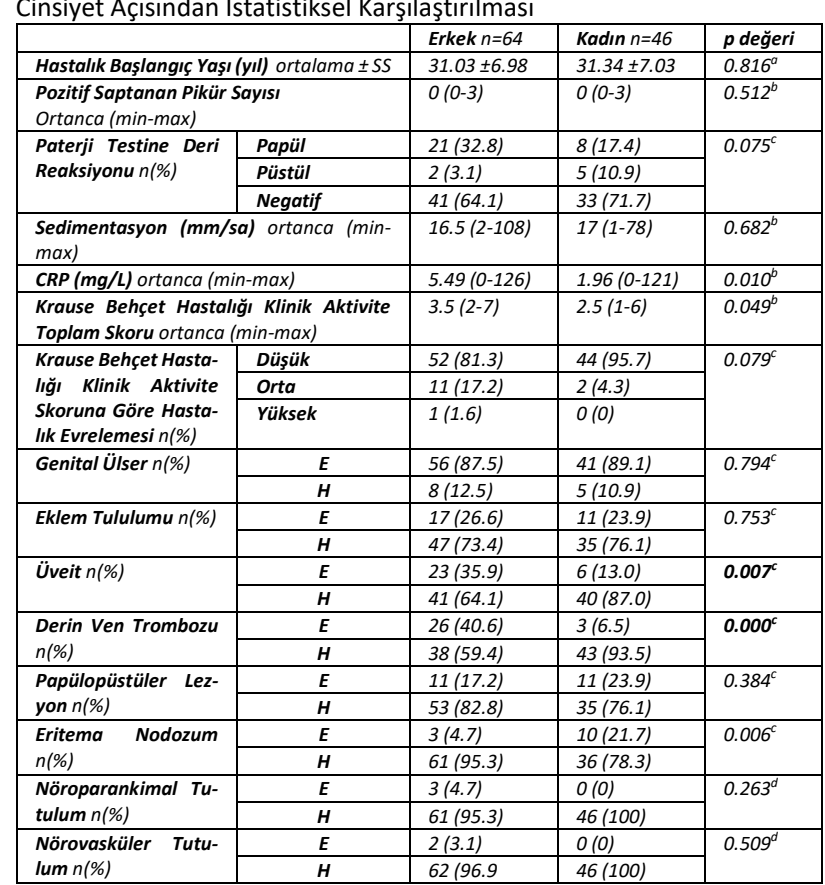

Anlamlılık düzeyi $p<0.05$, a: Independent sample t-test. $b$ : Mann Whitney U testi c: Pearson $\chi^{2}$ testi, $d$ : Fisher Exact test, E: Evet, $H$ : Hayır, CRP: C-Reaktif Protein, SS: Standart sapma, min: minimum, max: maksimum, $\mathrm{mm}$ : milimetre, sa: saat, mg: miligram, L: Litre

Çalışmaya dahil olan $\mathrm{BH}^{\prime}$ li hastaların Krause Behçet HastaIığı Klinik Aktivite Toplam Skoru ortanca değeri 3 (1-7) idi. Yine bu skora göre hastaların 96 'sı (\% 87.3) düşük hastalık aktivitesine sahip iken $13^{\prime}$ ü (\% 11.8) orta hastalık aktivitesine, 1'i de (\% 0.9) yüksek hastalık aktivitesine sahipti. Çaıışmaya dahil olan hastaların tamamı aktif dönem (düşük, orta veya yüksek) hastalardan oluşuyordu.

Paterji testi pozitifliği olan hastaların yaş ortalaması 31.63 \pm 6.40 (yıl) iken PT negatif olan hastaların yaş ortalaması $30.93 \pm 7.26$ (yı) idi. Çalışmamızda PT pozitif ve negatif olanlarda; yaş ortalaması bakımından istatistiksel açıdan anlamlı bir farklılık yoktu $(p=0.620)$. PT pozitif olan BH'lerde Krause Behçet Hastalığı Klinik Aktivite Toplam Skoru ortanca değeri 3 (1-6) iken PT negatif olanlarda bu değer 3 (1-7) idi. PT pozitif ve negatif olanlarda Krause Behçet Hastalığı Klinik Aktivite Toplam Skoru açısından istatistiksel anlamlı farklılık yoktu $(p=0.494)$. Tablo $1^{\prime}$ de $\mathrm{BH}^{\prime}$ ye ait sosyodemografik, laboratuvar ve klinik bulguların paterji test durumlarına göre istatistiksel açıdan karşılaştırılması görülmektedir. Tablo 2'de Behçet Hastalığına ait yaş, klinik ve laboratuvar bulgularının cinsiyet açısından istatistiksel karşılaştırılması görülmektedir.

Tablo 3'te BH'ye ait cinsiyet, laboratuvar ve klinik bulguların hastalık başlangıç yaş grupları açısından istatistiksel karşılaştırılması görülmektedir. 
Tablo 4.'te ise Behçetli hastalarda; hastalık başlangıç yaşı, laboratuvar bulguları, pozitif saptanan pikür sayısı ve hastalık aktivitesi toplam skoru arasındaki istatistiksel ilişki görülmektedir.

Tablo 3. Behçet Hastalı̆ına Ait Cinsiyet, Laboratuvar ve Klinik Bulguların Hastalık Başlangıç Yaş Grupları Açısından İstatistiksel Karşılaştııılması

\begin{tabular}{|c|c|c|c|c|}
\hline & & $\begin{array}{l}\text { Klasik Yaş } \\
\text { Başlangıçlı } \\
\text { Grup }(<\mathbf{4 0}) \\
n=102\end{array}$ & $\begin{array}{l}\text { Geç Yaş } \\
\text { Başlangıçlı } \\
\text { Grup }(\geq \mathbf{4 0}) \\
n=8\end{array}$ & $\begin{array}{l}\mathbf{p} \\
\text { değeri }^{a}\end{array}$ \\
\hline \multirow[t]{2}{*}{ Cinsiyet $\mathrm{n}(\%)$} & Erkek & $59(57.8)$ & $5(62.5)$ & \multirow[t]{2}{*}{$1.000^{\mathrm{a}}$} \\
\hline & Kadın & $43(42.2)$ & $3(37.5)$ & \\
\hline \multirow[t]{2}{*}{ Paterji Test Durumu n(\%) } & Pozitif & $34(33.3)$ & $2(25.0)$ & \multirow[t]{2}{*}{$1.000^{\mathrm{a}}$} \\
\hline & Negatif & $68(66.7)$ & $6(75.0)$ & \\
\hline \multirow{3}{*}{$\begin{array}{l}\text { Paterji Testine } \\
\text { Reaksiyonu } \mathrm{n}(\%)\end{array}$} & Papül & 27 (26.5) & $2(25.0)$ & \multirow[t]{3}{*}{$0.729^{b}$} \\
\hline & Püstül & $7(6.9)$ & $0(0)$ & \\
\hline & Negatif & $68(66.7)$ & $6(75.0)$ & \\
\hline \multicolumn{2}{|c|}{$\begin{array}{l}\text { Pozitif Saptanan Pikür Sayısı } \\
\text { Ortanca (min-max) }\end{array}$} & $0(0-3)$ & $0(0-1)$ & $0.430^{c}$ \\
\hline \multicolumn{2}{|c|}{$\begin{array}{l}\text { Sedimentasyon (mm/sa) ortanca (min- } \\
\text { max) }\end{array}$} & $16(1-108)$ & $23(1-94)$ & $0.314^{c}$ \\
\hline \multirow{2}{*}{\multicolumn{2}{|c|}{$\begin{array}{l}\text { CRP (mg/L) ortanca (min-max) } \\
\text { Krause Behçet Hastalı̆ı Klinik Ak- } \\
\text { tivite Toplam Skoru ortanca (min-max) }\end{array}$}} & $4.15(0-126)$ & $5.3(0-32)$ & $0.963^{c}$ \\
\hline & & $3(1-7)$ & $2(2-6)$ & $0.384^{c}$ \\
\hline \multirow{3}{*}{$\begin{array}{l}\text { Krause Behçet Hastalığı } \\
\text { Klinik Aktivite Skoruna } \\
\text { Göre Hastalık Evrelemesi } \\
\text { n(\%) }\end{array}$} & Düşük & $89(87.3)$ & $7(87.5)$ & \multirow[t]{3}{*}{$0.960^{\mathrm{b}}$} \\
\hline & Orta & $12(11.8)$ & $1(12.5)$ & \\
\hline & Yüksek & $1(1.9$ & $0(0)$ & \\
\hline \multirow[t]{2}{*}{ Genital Ülser n(\%) } & E & $91(89.2)$ & $6(75.0)$ & \multirow[t]{2}{*}{$0.240^{\mathrm{a}}$} \\
\hline & $\mathbf{H}$ & $11(10)$ & $2(25.9)$ & \\
\hline \multirow[t]{2}{*}{ Artrit n(\%) } & $\mathbf{E}$ & $26(25.5)$ & $2(25.0)$ & \multirow[t]{2}{*}{$1.000^{\mathrm{a}}$} \\
\hline & $\mathbf{H}$ & $76(74.5)$ & $6(75.0)$ & \\
\hline \multirow[t]{2}{*}{ Üveit n(\%) } & $\mathbf{E}$ & $28(27.5)$ & $1(12.5)$ & \multirow[t]{2}{*}{$0.678^{\mathrm{a}}$} \\
\hline & $\mathbf{H}$ & $74(72.5)$ & $7(87.5)$ & \\
\hline \multirow{2}{*}{$\begin{array}{lll}\begin{array}{l}\text { Derin } \\
\mathrm{n}(\%)\end{array} & \text { Ven } & \text { Trombozu } \\
\end{array}$} & $\mathbf{E}$ & $27(26.5)$ & $2(25.0)$ & \multirow[t]{2}{*}{$1.000^{\mathrm{a}}$} \\
\hline & $\mathbf{H}$ & 75 (73.5) & $6(75.0)$ & \\
\hline \multirow{2}{*}{$\begin{array}{l}\text { Papülopüstüler Lezyon } \\
\mathrm{n}(\%)\end{array}$} & E & $21(20.6)$ & $1(12.5)$ & \multirow[t]{2}{*}{$1.000^{\mathrm{a}}$} \\
\hline & $\mathbf{H}$ & $81(79.4)$ & $7(87.5)$ & \\
\hline \multirow[t]{2}{*}{ Eritema Nodozum n(\%) } & $\mathbf{E}$ & $13(12.7)$ & $0(0)$ & \multirow[t]{2}{*}{$0.592^{\mathrm{a}}$} \\
\hline & $\mathbf{H}$ & 89 (87.3) & $8(100)$ & \\
\hline \multirow{2}{*}{$\begin{array}{l}\text { Nöroparankimal } \\
\text { lum } n(\%)\end{array}$} & $\mathbf{E}$ & $2(2.0)$ & $1(12.5)$ & \multirow[t]{2}{*}{$0.204^{\mathrm{a}}$} \\
\hline & $\mathbf{H}$ & $100(98.0)$ & $7(87.5)$ & \\
\hline \multirow{2}{*}{$\begin{array}{l}\text { Nörovasküler } \\
\mathrm{n}(\%)\end{array}$} & $\mathbf{E}$ & $2(2.0)$ & $0(0)$ & \multirow[t]{2}{*}{$1.000^{\mathrm{a}}$} \\
\hline & $\mathbf{H}$ & $100(98.0)$ & $8(100)$ & \\
\hline
\end{tabular}
anlamlılık düzeyi $p<0.05$, a: Fisher Exact Test, $b$ : Pearson $\chi 2$ Test, $c$ : Mann Whitney U testi, E: Evet, H: Hayir, CRP: C-Reaktif Protein, SS: Standart sapma, min: minimum, max: maksimum, $\mathrm{mm}$ : milimetre, sa: saat, mg: miligram, L: Litre

Tablo 4. Behçet Hastalarında Hastalık Başlangıç Yaşı, Laboratuvar Bulguları, Pozitif Saptanan Pikür Sayısı ve Hastalık Aktivitesi Toplam Skoru Arasındaki İstatistiksel ilişkisi

\begin{tabular}{|c|c|c|c|c|c|c|}
\hline & & $\begin{array}{l}\text { HB Yaşı } \\
\text { (yıl) }\end{array}$ & $\begin{array}{l}\text { Sedim } \\
(\mathrm{mm} / \mathrm{sa})\end{array}$ & $\begin{array}{l}\text { CRP } \\
\text { (mg/L) }\end{array}$ & $\begin{array}{l}\text { PS Pikür } \\
\text { Sayısı }\end{array}$ & $\begin{array}{l}\text { Krause } \\
\text { BHKAT } \\
\text { Skoru }\end{array}$ \\
\hline \multirow[t]{2}{*}{ HB Yaşı (yıl) } & $r$ & 1 & 0.122 & 0.081 & 0.020 & -0.022 \\
\hline & $p^{a}$ & & 0.206 & 0.399 & 0.838 & 0.817 \\
\hline \multirow{2}{*}{$\begin{array}{l}\text { Sedim } \\
\text { (mm/sa) }\end{array}$} & $r$ & 0.122 & 1 & 0.567 & -0.013 & 0.293 \\
\hline & $\mathrm{p}^{\mathrm{a}}$ & 0.206 & & 0.000 & 0.891 & 0.002 \\
\hline \multirow[t]{2}{*}{ CRP (mg/L) } & $r$ & 0.081 & 0.567 & 1 & -0.092 & 0.301 \\
\hline & $p^{a}$ & 0.399 & 0.000 & & 0.340 & 0.001 \\
\hline \multirow[t]{2}{*}{ PS Pikür Sayısı } & $r$ & 0.020 & -0.013 & -0.092 & 1 & -0.070 \\
\hline & $p^{a}$ & 0.838 & 0.891 & 0.340 & & 0.466 \\
\hline \multirow{2}{*}{$\begin{array}{l}\text { Krause } \\
\text { BHKAT Skoru }\end{array}$} & $r$ & -0.022 & 0.293 & 0.301 & -0.070 & 1 \\
\hline & $p^{a}$ & 0.817 & 0.002 & 0.001 & 0.466 & \\
\hline
\end{tabular}

Anlamlılık düzeyi $p<0.05$, a: Spearman korelasyon testi, $p$ : $p$ değeri, $r$ : korelasyon katsayısı, HB: Hastalık Başlangıç, Sedim: Sedimentasyon, CRP: C-Reaktif Protein, PT: Paterji Testi, PS: Pozitif Saptanan, BHKAT: Behçet Hastalığı Klinik Aktivite Toplam, mm: milimetre, sa: saat, mg: miligram, L: Litre

\section{Tartışma}

Paterji testi, BH tanısında olası tutulum yerlerini ve prognozu belirlemede kullanılabileceği söylenen tarihi bir testtir (13). PT pozitifliği ile BH'nin klinik aktivitesi arasındaki ilişki literatürde oldukça çelişkilidir. PT pozitifliğinin $\mathrm{BH}^{\prime}$ nin şiddetinden çok testin yapıldığı dönemdeki hasta- lık aktivitesine bağlı olduğunu savunanlar olduğu gibi hastalık aktivitesi ile ilişkisi olmadığını savunanlarda vardır (14-17).

Literatürde Krause ve ark.larının 43 Behçet tanılı hastada yapmış olduğu bir çalışmada, bizim çalışmamıza benzer şekilde PT ile hastalığın başlangıç yaşı, cinsiyeti, mukokütanöz ve sistemik bulguların (üveit, DVT, artrit, Gis tutulumu, nörobehçet ) sıklıkları açısından herhangi bir farklılık saptanmamıştır (15). Bunun aksine Koç ve ark.ları, BH'lilerde yapmış oldukları bir çalışmada, vasküler tutulumu olan ve dolayısıyla daha şiddetli hastalığı olanlar da PT pozitifliğini daha yüksek bulmuşlardır (16).

Assar ve ark.ları 1675 BH'yi dahil ettikleri bir kohort çalışmasında; PT pozitiflik sıklığını (\% 50,2), bizim çalışmamız sonuçlarından oldukça yüksek bulmuşlardır (17). Assar ve ark.larının bu çalışmasında ayrıca PT pozitifliği; erkek hastalarda, OA, PPL ve anterior üveit olanlar da daha sık bulunmuşken, retinit ve vaskülit gibi şiddetli organ tutulumu olanlarda bu artmış sıklık bulunamamıştır (17). Assar ve ark.larının çalışmasının, bizim çalışma sonuçlarımız ile uyumlu olan tarafı; PT durumu açısından, hastaların yaş ortalamalarının benzer olmasıdır (17).

Gül ve ark. aktif 80 BH'de, ön kol derisi, oral mukoza ve erkek hastalarda skrotum ve kadın hastalarda ise labium majus derisine PT uygulayarak pozitiflik sıklıklarını araştırmışlardır (18). Bu çalışmada oral PT pozitifliği \% 42,5 iken ön kol PT pozitifliği \% 18,5, genital PT pozitifliği ise \% 7,5 bulunmuştur (18). Literatürde Dilsen ve ark.ları künt iğne ile yapılan PT pozitiflik sıklıklarını, keskin iğne ucu ile yapılana göre daha yüksek saptamışlardır (10). Kalay ve ark.larıda BH'de eş zamanlı olarak intradermal PT'yi üç aşamalı PT (ardışık üç gün, antekübital vene intravenöz punktur ve kalça üst dış kadranına intramüsküler yol ile $1 \mathrm{ml}$. salin enjeksiyonu yapılmış) ile karşılaştırmış ve sonuç olarak üç aşamalı PT pozitiflik sıklığını (\% 43,3), intradermal pozitiflik sıklığından (\%30) daha yüksek bulmuşlardır (19). Yine bu çalışmada erkek cinsiyette, üç aşamalı PT pozitifliği daha sık iken, hastalık aktivitesi ile PT pozitifliği arasında bizim çalışmamızda olduğu gibi herhangi bir farklılık saptamamışlardır (19). Azizlerli ve ark.ları ise yerleşik BH'lerde $\mathrm{PT}$ 'nin pozitiflik sıklığını \%74.5 bulurken yeni tanı almış aktif $\mathrm{BH}^{\prime}$ lilerde \% 64.8 olarak bulmuşlardır (20).

Paterji test sonuçlarının popülasyonlar arasında ve hatta aynı popülasyonu inceleyen farklı araştırmacılar arasında büyük ölçüde değiştiği bilinmektedir. BH'de paterji pozitifliği, Orta Doğu, Uzak Doğu ve Akdeniz Havzasını içeren İpek Yolu üzerindeki ülkelerde en yüksektir (21). Aksine, $A B D$, İngiltere ve diğer Kuzey Avrupa ülkelerinden gelen BH'lerde paterji pozitifliği önemli ölçüde düşük olduğu göze çarpmaktadır (21). Çok sayıda çalışma, 1980'lerden bu yana zaman içinde pozitif PT yaygınlığında bir düşüş olduğunu da göstermiştir (22).

Prosedürde kullanılan iğnenin çapı da testin sonuçlarını etkiler, daha kalın 20 gauge'lık iğneler daha fazla cilt travmasına neden olur ve $\mathrm{BH}^{\prime}$ de pozitif bir sonuca neden olma olasılığını artırır. Ek olarak, iğne batmasından önce cildin 
cerrahi olarak temizlenmesinin testi etkilediği ve pozitiflik sıklığının azalmasına neden olacağı da gösterilmiştir (23). Pozitif bir testin yorumlanmasındaki farklılıklar kadar PT uygulama protokolleri üzerinde fikir birliği olmaması da, farklı pozitiflik sıklıklarının gözlenmesine neden olabilir (24).

Behçet hastalarında PT sonucunu etkileyebilecek bir diğer hususta, bazı çalışmalara göre yanlış negatif sonuçları artırabilen kortikosteroid kullanımıdır (22). Literatürde; BH'lerde, PT sırasında immunsüpresan ilaç kullanılmıyor ise testin yüksek olasılıkla pozitif geleceği bildirilmiştir (25). Bunun aksine, bazı araştırmacılar ise sistemik kortikosteroid kullanımının PT'nin histolojisini veya genel görünümünü değiştirmediğini savunmuşlardır (12). Bizim çalışmamızda hastalığın başlangıç dönemine ait veriler sunulduğundan hiçbir hasta immunsüpresif tedavi almıyordu.

Behçet Hastalığı genellikle 15-40 yaş arası genç erişkinleri etkilemekle birlikte farklı yaş gruplarında da görülebilmektedir. Çocukluk çağında ve 40 yaşın üstünde başlaması seyrektir. Genç erkek hastalarda hastalığın daha ağır seyrettiği ve yaşla birlikte hastalık aktivitesinin azaldığı bilinmektedir (26). Guzelant ve ark.larının yapmış oldukları bir çalışmada geç başlangıçlı ve klasik başlangıçlı BH karşılaştırılmış ve paterji pozitifliği, OA, GÜ, PPL, üveit, artrit sıklığı bizim çalışma sonuçlarımıza benzer şekilde farklı bulunmaz iken EN sıklığı klasik başlangıçlı grupta daha fazla bulunmuştur (27).

Çalışmamızın limitasyonları, sonuçlarımızın tek merkez verilerinden oluşması ve çalışmanın retrospektif olmasıdır. Çalışmamızın güçlü yönü çalışmaya dahil olan hasta sayımızın yüksek olması, sadece PT'nin pozitif, negatif olma durumu değil aynı zamanda paterji şiddetinin, pozitif saptanan pikür sayısının da gruplar arasında karşılaştırılmış olmasıdır. Yine klasik ve geç başlangıçlı BH'yi kategorize edip hastalığın klinik aktivitesi de dahil olmak üzere bir çok değişkenle karşılaştırmış olmamız da çalışmanın güçlü yönleri arasına eklenebilir.

Sonuç

Bizim çalışmamızı ve literatürdeki diğer çalışmaları topluca düşündüğümüzde PT pozitifliğinin hastalığın klinik aktivitesini tahmin etmede ve $\mathrm{BH}$ için tedaviyi düzenlemede yararının halen tartışmalı olduğunu ve daha fazla araştırma gerektirdiğini ifade etsek yanlış olmayacaktır. Belki de PT'nin duyarlılığını artıracak yeni, standardize test yöntemleri bu belirsizliği çözecek ve biz klinisyenler için testi daha değerli hale getirecektir.

Etik onam: Çalışma protokolü Karabük Üniversitesi Tıp Fakültesi yerel etik kurulu tarafından onaylandı (tarih: 16.11.2020, karar sayısı: E-77192459-050.99-47176). Çalışma Helsinki Bildirgesi ilkelerine uygun olarak yapıldı.

\section{Yazar Katkıları:}

Konsept: Y.D.

Literatür Tarama: Y.D.

Tasarımı: Y.D.

Veri toplama: Y.D.
Veri analizi ve yorumlama: Y.D.

Makale yazımı: Y.D.

içeriğin eleştirel incelenmesi: Y.D.

Çıkar Çatışması: Herhangi bir çıkar çatışmamız bulunmamaktadir.

Finansal Destek: Araştırma kapsamında herhangi bir kurum ya da kuruluştan finansal destek sağlanmamıştır.

\section{Kaynaklar}

1. Onder M, Gürer MA. The multiple faces of Behçet's disease and itsa etiological factors. J Eur Acad Dermatol Venereol. 2001;15(2):126-36.

2. Saylan T, Mat C, Fresko I, Melikoğlu M. Behçet's disease in the Middle East. Clin Dermatol. 1999;17(2):209-23; discussion 105-6.

3. Yurdakul S, Hamuryudan V, Yazici H. Behçet syndrome. Curr Opin Rheumatol. 2004;16(1):38-42.

4. Criteria for diagnosis of Behçet's disease. International Study Group for Behçet's Disease. Lancet. 1990;335(8697):1078-80.

5. Blobner F. Zurrezidivierenden Hypopyoniritis. Z Augenheilkd 1937;91:129-39.

6. Ozluk E, Balta I, Akoguz O, Kalkan G, Astarci M, Akbay G, et al. Histopathologic Study of Pathergy Test in Behçet's Disease. Indian J Dermatol. 2014 Nov;59(6):630.

7. Askari A, Al-Aboosi M, Sawalha A. Evaluation of pathergy test in North Jordan. Clin Rheumatol. 2000;19(3):249-51.

8. Ozarmagan G, Saylan T, Azizlerli G, Ovül C, Aksungur VL. Re-evaluation of the pathergy test in Behçet's disease. Acta Derm Venereol. 1991;71(1):75-6.

9. Sungur G, Hazirolan D, Hekimoglu E, Kasim R, Duman S. Late-onset Behçet's disease: demographic, clinical, and ocular features. Graefes Arch Clin Exp Ophthalmol. 2010 Sep;248(9):1325-30.

10. Dilşen N, Koniçe $M$, Aral O, Ocal L, Inanç M, Gül A. Comparative study of the skin pathergy test with blunt and sharp needles in Behçet's disease: confirmed specificity but decreased sensitivity with sharp needles. Ann Rheum Dis. 1993 Nov;52(11):823-5.

11. Krause I, Mader R, Sulkes J, Paul M, Uziel Y, Adawi M, et al. Behçet's disease in Israel: the influence of ethnic origin on disease expression and severity. J Rheumatol. 2001;28(5):1033-6.

12. Hinkle DE, Wiersma W, Jurs SG. Applied statistics for the behavioral sciences. Houghton Mifflin College Division; 2003.

13. Tunç R, Uluhan A, Melikoğlu $M$, Ozyazgan $Y$, Ozdoğan $H$, Yazici H. A reassessment of the International Study Group criteria for the diagnosis (classification) of Behçet's syndrome. Clin Exp Rheumatol. 2001 Sep-Oct;19(5 Suppl 24):S45-7.

14. Alpsoy E. Behçet's disease: A comprehensive review with a focus on epidemiology, etiology and clinical features, and management of mucocutaneous lesions. J Dermatol. 2016 Jun;43(6):620-32.

15. Krause I, Molad Y, Mitrani M, Weinberger A. Pathergy reaction in Behçet's disease: lack of correlation with mucocutaneous manifestations and systemic disease expression. Clin Exp Rheumatol. 2000;18(1):71-4.

16. Koç Y, Güllü I, Akpek G, Akpolat T, Kansu E, Kiraz S, et al. Vascular involvement in Behçet's disease. J Rheumatol. 1992 Mar;19(3):402-10. 
17. Assar S, Sadeghi B, Davatchi F, Ghodsi SZ, Nadji A, Shahram $F$, et al. The association of pathergy reaction and active clinical presentations of Behçet's disease. Reumatologia. 2017;55(2):79-83.

18. Gül U, Gönül M. Oral and genital pathergy in Behçet's disease. Dermatology. 2007;215(1):80-1.

19. Kalay Yildizhan I, Boyvat A. Diagnostic Sensitivity of Different Applications of Pathergy Test for Behçet's Disease. Arch Rheumatol. 2019 Apr 15;35(1):29-34

20. Azizlerli G, Köse AA, Sarica R, Gül A, Tutkun IT, Kulaç M, et al. Prevalence of Behçet's disease in Istanbul, Turkey. Int J Dermatol. 2003 Oct;42(10):803-6.

21. Sequeira FF, Daryani D. The oral and skin pathergy test. Indian J Dermatol Venereol Leprol. 2011;77(4):526-30.

22. Davatchi F, Chams-Davatchi C, Ghodsi Z, Shahram F, Nadji A, Shams H, et al. Diagnostic value of pathergy test in Behcet's disease according to the change of incidence over the time. Clin Rheumatol. 2011 Sep;30(9):1151-5. doi:

23. Kutlubay $Z$, Tüzün $Y$, Wolf R. The Pathergy Test as a Diagnostic Tool. Skinmed. 2017;15(2):97-104.

24. Rahman S, Daveluy S. Pathergy Test. 2020 Jun 9. In: StatPearls [Internet]. Treasure Island (FL): StatPearls Publishing; 2020 JaN

25. Varol A, Seifert $O$, Anderson CD. The skin pathergy test: innately useful? Arch Dermatol Res. 2010 Apr;302(3):155-68.

26. Kural-Seyahi E, Fresko I, Seyahi N, Ozyazgan $\mathrm{Y}$, Mat C, Hamuryudan $\mathrm{V}$, et al. The long-term mortality and morbidity of Behçet syndrome: a 2-decade outcome survey of 387 patients followed at a dedicated center. Medicine (Baltimore). 2003 Jan;82(1):60-76.

27. Guzelant $G$, Ozyazgan $Y$, Mat $C$, Hamuryudan $V$, Yazici $H$, Seyahi E. Clinical Characteristics of Older Age-Onset Behçet Syndrome Patients. Arthritis Rheumatol. 2018; 70 (suppl 10). https://acrabstracts.org/abstract/clinicalcharacteristics-of-older-age-onset-behcet-syndromepatients/. Accessed February 20, 2021. 